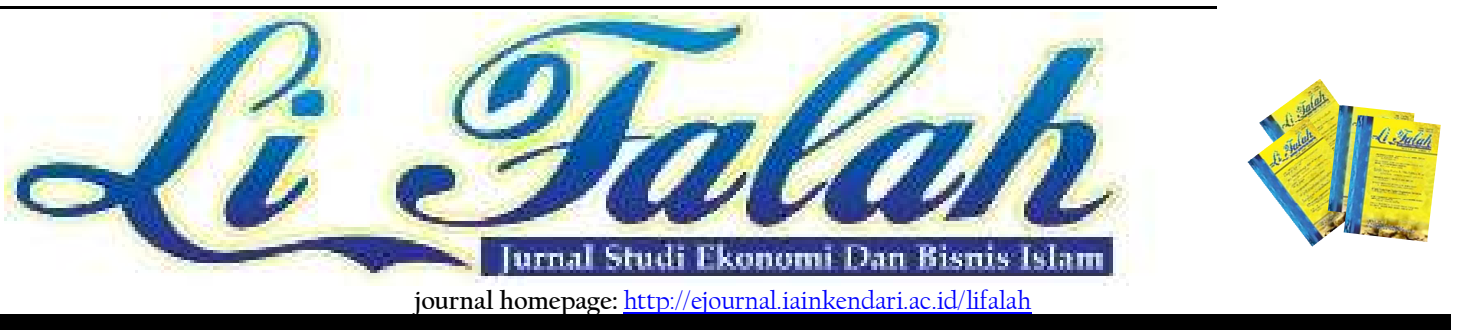

\title{
Millennial and Islamic Financial Products
}

\section{Diyan Lestari}

Faculty of Business, Institut Teknologi dan Bisnis Kalbis, Jakarta Email: diyan.lestari@kalbis.ac.id

\section{INFO ARTIKEL}

Keywords:millennial, Islamic finance, behavior

DOI:

http://dx.doi.org/10.31332/lifalah.v5il.1755
A B S T R AC T
Islamic financial products have quite different characteristic compare to conventional financial products, especially related to fundamental principle. Islamic finance should implement sharia law which consider Islamic rule in Quran and Hadist. The rise of Indonesian millennial awareness in Islamic products impact on how firms conduct their business, especially related to financial products because they are relatively complex. This paper attempts to provide an understanding related to millennial consideration in Islamic financial products which examine several aspects, such as Islamic financial literacy, Islamic lifestyle, perceive risk, and social influence. Smart PLS is used to analyze 600 data in order to provide statistical result. Purposive sampling is a technique that this paper used to classified research data. The finding indicates that all variables have strong relationship to determine Islamic financial products decision making. Most variables impact millennial behavior in using financial products, except perceive risk and social influence. The result of this study also provides practical implication for Islamic finance institution, government, academic, and business owner.

\section{Introduction}

The tech disruption, cyber security, elections, trade war, health issue, etc are several factors that may drive sentiment and encourage firms including financial institution to compete. Indonesia is expected to have stable economy in 2020. In general, household spending contributes 
for almost $60 \%$ of total Indonesia national income. Thus, individual personal finance should be well managed to improve the ecnomic growth. Indonesian muslim that belong to millennial generation are charaterized as adaptable, democratic, and open minded in facing the challanging modern society. In general, some of Indonesian millennial prefer to allocate their money on islamic financial products since sharia principles require several procedures such as non-alcohol investment, profit-loss sharing system (it is perceived as less risky product), and do not implement "riba" (Ashor, 2018). The rapid changes of technology cause the islamic product innovation which offers many options to optimize individual portofolio structure.

Muslim population has increased steadily since 1870. Kettani (2010) stated that in 1870 , the population reached $15 \%$ growth, and $26 \%$ in 1950, while it is expected to have stable growth (approximately 26\% by 2020, and reach $34 \%$ of world population by 2070). The vast muslim population should be anticipated by transforming products that meet their need, including financial products. It is important since financial institution becomes one of the most critical instruments to help people to manage their money. The popularity of islamic finance was promoted by the existance of islamic empire and the boom of trading activities which required intermediary institution to facilitate several financial services such as transfer, lending and deposit, etc (Alharbi, 2015).

Generally, there are many Islamic financial institutions in Indonesia with various products and Sharia practices become more well known among muslim in Indonesia. Moreover, Islamic banking in Indonesia showed relatively strong growth which account for $19.83 \%$ of its asset, $15.23 \%$ in financing, and $19.83 \%$ of its deposits (Otoritas Jasa Keuangan, 2018). The basic principle of Islamic finance principle is sharia (islamic law) which involves not only financial transaction in formal financial instution, but also nonformal financial institution (Imady \& Seibel, 2006). The sharia implementation is seen as attractive component by Indonesian muslim in complex decision making process.

The rise of people awareness to conduct financial planning cause the decision maker (of institution) should consider determinants that influence personal financial management which basically consists of several activities, such as saving, investment, expenditure allocation, insurance, debt proportion, pension decision, real estate, tax planning, etc (Gedmintiene \& Visockaite, 2016). According to previous studies, personal 
finance decision is strongly determined by several aspects, for instance financial literacy, perceived risk, lifestyle, and social factors (Putri \& Lestari, 2019; Kim \& et.al., 2017; Mohiuddin, 2018; Lestari, 2019; Hong $\&$ Yi, 2012). This paper attempt to examine Indonesian muslim (millennial generation) personal finance behavior related to islamic financial products which is insvestigated by the social factors, islamic financial literacy, and perceived risk in Jabodetabek (Jakarta, Bogor, Depok, Tangerang, Bekasi) since the cities are center of Indonsian business, and possess fast muslim pupulation.

Internet basically promotes easy access of information. It helps individual to improve literacy, including islamic financial literacy. The better literacy is expected to have better undertanding in managing money. Islamic principles require several practical implementation and the rise of sharia awareness will lead individual to have better understanding in islamic finance. The better understanding of islamic finance is expected to drive millennial intention in using islamic financial products. In general, the proper Islamic financial literacy level not only drive individual intention but also help them to make better decision in financial products consideration. Previous studies have been discussed the financial literacy aspect in decision making prosess (Putri \& Lestari, 2019); Kim \& et.al. (2017).

Islamic culture has become critical feature in Indonesia culture. It can be showed by Indonesian habit and tradition that has been shifted, especially related to Indonesian outfit. Not only outfit consideration, but also related to food and baverage that shouls follow sharia law, for instance: the food and baverage consumption should implement the halal procedures. Basically, islamic culture is the part of Indonesian lifestyle and the islamic lifetsyle practice is expected to drive individual intention to use islamic financial products, and individual usually prefer to use islamic financial product in the actual behavior. Lifestyle, is considered as important determinant for individual decision making process Al-Dmour \& et. al (2017); Anitha (2016).

Financial products decision making is quite complex since it involves the risk return consideration. Islamic finance which conducts the profit and loss sharing mechanisme is perceived as a safe product and do not have bad impact on society since islamic finance practice is free from "riba". The finance literature explain the relationship between risk and return which stated that the low return is followed by the low return and vice versa. Basically, individual require the optimal return in minimal risk financial products. If 
the financial product is perceived as low risk with optimal return, it will lead to high intention to use the product and help individual to make fast financial consideration. Previous studies considered the perceived risk as one of essential aspect in individual behavior Hong \& Yi (2012)

According to Suhartono (2018), Indonesian millennial began to dominate the stock market investment for the last two years with $34 \%$ of investment is conducted by the people aged 20s. However, the fisrt choice of financial product is saving account which account for $64.7 \%$. Furthermore, during the decision process millennials prefer to consult with family and friends, followed by financial website and social media, financial $\mathrm{tv} \mathrm{ad}$, and financial consultant (Jakpat, 2018). The data basically represent several considerations which is made prior to personal finance decision. Technology influences how people allocate their asset and invest their money that are imporant ingredient of personal finance. It is expected that social influence will improve Indonesian millennial intention and affect the individual actual behavior in islamic financial product consideration.

This paper attempt to provide several contributions related to individual behavior in using islamic financial products. This study extends the individual behavior literature which include financial aspect (risk-return consideration), islamic aspect (islamic financial literacy and islamic lifestyle). According to TPB (Theory of Planned Behavior) and TRA (Theory of Reasoned Action), intention becomes important factor to explain actual behavior and this paper aims to describe millennial decision making process from several factors that affect intention and milllennial actual behavior.

\section{Research Method}

This study focuses to examine the Islamic products consideration among Indonesian millennial. Variables in this study are Islamic financial literacy, social factor, lifestyle, perceived risk, intention, and Islamic product decision. The relationship among variables are analyzed by using structural equation modeling which represents one of the procedures in quantitative research. Quantitative resesearch is an approach to respond questions in conducting research by using numerical data (Williams, 2007).

\subsection{Data and Sample}

Primary data is used to examine the millennial behavior related to Islamic financial products. There are several criteria that should be considered to gain the data, for instance: respondents are muslim, they are 18-35 years old, possess 
Islamic financial products, and live in Jabodetabek (Jakarta, Bogor, Depok, Tangerang, and Bekasi), 600 respondents are valid as sample research. Data classification (following the purposive sampling technique) helps this study to obtain the appropriate sample which is conducted by both offline and online surveys.

\subsection{Data Analysis}

This paper attempts to examine the Islamic financial products consideration among Indonesian millennials which is analyzed by using structural equation modeling (SEM). SEM is basically a statistical technique which is classified as multivariate analysis and is employed to investigate the structural relationship. To test the model construct, this study applies the smart partial least square (smart PLS). The smart PLS generally assessments tool to help utilizing the statistical estimation which uses three steps of analysis, including outer model, inner model, and hypothesis analysis. To conduct the validity test in Smart PLS, it is measured by employing the convergent validity test, discriminant validity test, and reliability test.

\subsection{Survey Instrument}

It is important to develop the appropriate survey instrument in order to gain insight from millennial who experience in Islamic financial products, this study formulates questionnair according to several previous studies with a slight adjustment. To measure Islamic financial literacy, this paper considers several items from Lusardi, 2008; Lopus, Amidjono, \& Grimes, 2019; Janor \& et. al., 2016. While perceived risk is measured by items in Trang \& Tho, 2017; Sindhu \& Kumar, 2014. Islamic lifestyle is developed by modifying several points from Anitha (2016); Al-Dmour \& et. Al. (2017). Intention and financial decision are modified by adopting points in Lestari (2019); Trang \& Tho (2017); Anitha (2016); Al-Dmour \& et. al (2017)

\subsection{Hypothesis}

$\mathrm{Hl}$ : Islamic financial literacy affects millennial intention in using islamic financial products

$\mathrm{H} 2$ : Islamic financial literacy effects millennial decision in using islamic financial products

H3: Islamic lifestyle affects millennial intention in using islamic financial products

H4: Islamic lifestyle affects millennial decision in using islamic financial products 
H5: Perceive risk affects millennial intention in using islamic financial products

H6: Perceive risk affects millennial decision in using islamic financial products

H7: Social influence affects millennial intention in using islamic financial products
H8: Social influence affects millennial decision in using islamic financial products H9: Intention affects millennial decision in using islamic financial products

Table 1 Respondent Profile

\begin{tabular}{|c|c|c|c|}
\hline Item & Categories & Freq & $\%$ \\
\hline \multirow[t]{2}{*}{ Gender } & Male & 180 & $30.00 \%$ \\
\hline & Female & 420 & $70.00 \%$ \\
\hline \multirow[t]{3}{*}{ Age (in years) } & 18-25 tahun & 360 & $60.00 \%$ \\
\hline & 26-30 tahun & 138 & $23.00 \%$ \\
\hline & 31-35 tahun & 102 & $17.00 \%$ \\
\hline \multirow{10}{*}{$\begin{array}{l}\text { Montly } \\
\text { Expenditure }\end{array}$} & & & \\
\hline & $<2,000,000$ & 192 & $32.00 \%$ \\
\hline & $2,000,000$ & & \\
\hline & $5,000,000$ & 240 & $40.00 \%$ \\
\hline & $5,000,001-$ & & \\
\hline & $10,000,000$ & 108 & $18.00 \%$ \\
\hline & $10,000,001-$ & & \\
\hline & $15,000,000$ & 42 & $7.00 \%$ \\
\hline & $>15,000,000$ & 18 & $3.00 \%$ \\
\hline & $\begin{array}{l}\text { Employee in } \\
\text { private/ state }\end{array}$ & & \\
\hline \multirow[t]{7}{*}{ Occupation } & company & 210 & $35.00 \%$ \\
\hline & University & & \\
\hline & student & 276 & $46.00 \%$ \\
\hline & Housewife & 48 & $8.00 \%$ \\
\hline & $\begin{array}{l}\text { Civil Servant } \\
\text { (PNS) }\end{array}$ & 36 & $6.00 \%$ \\
\hline & Enterpreneur & 18 & $3.00 \%$ \\
\hline & Freelancer & 12 & $2.00 \%$ \\
\hline \multicolumn{4}{|l|}{ Financial } \\
\hline \multirow[t]{6}{*}{ Products } & Saving account & 600 & $49.79 \%$ \\
\hline & Mutual fund & 60 & $4.98 \%$ \\
\hline & Equity & 120 & $9.96 \%$ \\
\hline & Deposit account & 250 & $20.75 \%$ \\
\hline & Insurance & 150 & $12.45 \%$ \\
\hline & Bond & 25 & $2.07 \%$ \\
\hline
\end{tabular}


Table 1 describes the profile of respondent in this study. According to the data, most of respondents are female (70\%420), while male only represents 30\% (180 respondents). 18-25 years old respondents dominate the survey activities and account for $60 \%$ (360 respondents). Most of respondents allocate their income in relatively low cost expenditure (Rp 2.000 .000 - Rp 5.000.000) which is exhibited by respondent profile data in table 1 . The number of individual who included in this classification is 240 respondents (40\%). The data also has meaningful explanation regarding to respondent occupation since majority of respondents are university students (276$46 \%$ ). Lastly, since respondents must own saving account, especially in sharia-based. It becomes the most popular financial products among respondents (60049.79\%).

\section{Result and Discussion}

3.1 Convergent Validity Convergent validity in smart PLS can be measured by using average variance extracted (AVE). Table 2 shows the result of convergent validity in this study which can be concluded that the construct is valid since the score is more that 0.5 .

Table 2 Convergent Validity

\begin{tabular}{lccc}
\hline & $\begin{array}{c}\text { Cronbach's } \\
\text { Alpha }\end{array}$ & $\begin{array}{c}\text { Composite } \\
\text { Reliability }\end{array}$ & $\begin{array}{c}\text { Average } \\
\text { Variance } \\
\text { Extracted } \\
\text { (AVE) }\end{array}$ \\
\hline \hline FD & 0.764 & 0.829 & 0.621 \\
INT & 0.827 & 0.865 & 0.593 \\
LK & 0.927 & 0.937 & 0.519 \\
LS & 0.702 & 0.782 & 0.538 \\
PR & 0.797 & 0.837 & 0.593 \\
SI & 0.772 & 0.830 & 0.559 \\
\hline \hline
\end{tabular}

\subsection{Discriminant Validity}

The next measurement is discriminant validity, which is represented by Table 3. Basically, discriminant validity measures the correlation among latent variables in every indicators. Discriminant validity requires correlation between latent variable and its indicator possess higher score compare to correlation to other indicators. Table 3 describes the result of discriminant validity which explains that every indicators experience the higher score of correlation between its indicator compare to other correlation. 
Table 3 Discriminant Validity

\begin{tabular}{lcccccc}
\hline & INT & FD & LK & LS & PR & SI \\
\hline \hline INT1 & 0.741 & 0.454 & 0.171 & 0.506 & 0.462 & 0.314 \\
INT10 & 0.801 & 0.296 & 0.275 & 0.320 & 0.319 & 0.362 \\
INT2 & 0.772 & 0.367 & 0.105 & 0.539 & 0.445 & 0.477 \\
INT3 & 0.735 & 0.243 & 0.108 & 0.415 & 0.341 & 0.395 \\
INT4 & 0.806 & 0.295 & 0.343 & 0.319 & 0.240 & 0.271 \\
INT5 & 0.775 & 0.344 & 0.301 & 0.270 & 0.266 & 0.320 \\
INT6 & 0.703 & 0.286 & 0.110 & 0.500 & 0.475 & 0.426 \\
INT7 & 0.794 & 0.362 & 0.402 & 0.447 & 0.397 & 0.423 \\
INT8 & 0.744 & 0.320 & 0.408 & 0.420 & 0.469 & 0.352 \\
INT9 & 0.766 & 0.300 & 0.149 & 0.551 & 0.415 & 0.387 \\
FD1 & 0.331 & 0.750 & 0.236 & 0.394 & 0.263 & 0.290 \\
FD2 & 0.417 & 0.722 & 0.260 & 0.417 & 0.328 & 0.218 \\
FD3 & 0.458 & 0.781 & 0.272 & 0.451 & 0.359 & 0.290 \\
FD4 & 0.353 & 0.753 & 0.478 & 0.317 & 0.202 & 0.181 \\
FD5 & 0.194 & 0.789 & 0.176 & 0.141 & 0.143 & 0.162 \\
FD6 & 0.164 & 0.870 & 0.259 & 0.127 & 0.067 & 0.174 \\
FD7 & 0.357 & 0.874 & 0.264 & 0.328 & 0.219 & 0.124 \\
LK1 & 0.208 & 0.225 & 0.763 & 0.150 & 0.212 & 0.141 \\
LK10 & 0.170 & 0.309 & 0.837 & 0.126 & 0.242 & 0.071 \\
LK11 & 0.254 & 0.244 & 0.768 & 0.252 & 0.372 & 0.121 \\
LK12 & 0.260 & 0.379 & 0.762 & 0.236 & 0.274 & 0.204 \\
LK13 & 0.342 & 0.391 & 0.782 & 0.278 & 0.354 & 0.213 \\
LK2 & 0.293 & 0.364 & 0.821 & 0.211 & 0.266 & 0.157 \\
LK3 & 0.236 & 0.283 & 0.798 & 0.202 & 0.255 & 0.121 \\
LK4 & 0.227 & 0.262 & 0.794 & 0.182 & 0.261 & 0.099 \\
LK5 & 0.212 & 0.261 & 0.793 & 0.184 & 0.267 & 0.110 \\
LK6 & 0.321 & 0.349 & 0.812 & 0.271 & 0.330 & 0.240 \\
LK7 & 0.293 & 0.300 & 0.755 & 0.240 & 0.389 & 0.107 \\
RP1 & 0.246 & 0.206 & 0.343 & 0.334 & 0.814 & 0.346
\end{tabular}




\begin{tabular}{lllllll} 
RP10 & 0.371 & 0.191 & -0.030 & 0.342 & 0.712 & 0.291 \\
RP11 & 0.406 & 0.269 & 0.006 & 0.414 & 0.730 & 0.277 \\
RP12 & 0.341 & 0.187 & 0.044 & 0.402 & 0.739 & 0.298 \\
RP13 & 0.417 & 0.318 & 0.498 & 0.415 & 0.720 & 0.304 \\
RP14 & 0.408 & 0.202 & 0.147 & 0.384 & 0.811 & 0.299 \\
RP2 & 0.050 & 0.097 & 0.232 & 0.075 & 0.747 & 0.023 \\
RP3 & 0.202 & 0.089 & 0.348 & 0.227 & 0.794 & 0.232 \\
RP4 & 0.340 & 0.206 & 0.011 & 0.301 & 0.767 & 0.234 \\
RP5 & 0.169 & 0.027 & 0.315 & 0.079 & 0.738 & 0.099 \\
RP6 & 0.092 & 0.041 & 0.367 & 0.107 & 0.855 & 0.143 \\
RP7 & 0.427 & 0.246 & 0.452 & 0.315 & 0.765 & 0.306 \\
RP8 & 0.474 & 0.281 & 0.330 & 0.346 & 0.750 & 0.362 \\
RP9 & 0.403 & 0.203 & 0.283 & 0.337 & 0.788 & 0.314 \\
SI1 & 0.299 & 0.137 & 0.068 & 0.353 & 0.316 & 0.751 \\
SI2 & 0.429 & 0.292 & 0.155 & 0.438 & 0.312 & 0.772 \\
SI3 & 0.279 & 0.070 & 0.092 & 0.265 & 0.169 & 0.849 \\
SI4 & 0.346 & 0.172 & 0.080 & 0.374 & 0.387 & 0.722 \\
SI5 & 0.518 & 0.288 & 0.190 & 0.490 & 0.413 & 0.771 \\
SI6 & 0.201 & 0.140 & 0.146 & 0.222 & 0.106 & 0.738 \\
SI7 & 0.426 & 0.198 & 0.174 & 0.383 & 0.367 & 0.704 \\
SI8 & 0.239 & 0.112 & 0.097 & 0.242 & 0.149 & 0.795 \\
SI9 & 0.346 & 0.186 & 0.141 & 0.332 & 0.272 & 0.800 \\
\hline \hline
\end{tabular}

3.3 Preliminary Reliability

Cronbach's Alpha and Composite

Reliability are used to measure the internal consistency reliability. Table 3 exhibits the reliability measurement which is evaluated by using cronbach's alpha and composite reliability. Every variables show the relatively high score of both cronbach;s alpha (> 0.6) and composite reliability (>0.6) which indicate all variables are reliable.

Table 4 Preliminary Reliability

\begin{tabular}{lccc}
\hline & $\begin{array}{c}\text { Cronbach's } \\
\text { Alpha }\end{array}$ & $\begin{array}{c}\text { Composite } \\
\text { Reliability }\end{array}$ & $\begin{array}{c}\text { Average } \\
\text { Variance } \\
\text { Extracted } \\
\text { (AVE) }\end{array}$ \\
\hline \hline FD & 0.764 & 0.829 & 0.621 \\
INT & 0.827 & 0.865 & 0.593 \\
LK & 0.927 & 0.937 & 0.519 \\
LS & 0.702 & 0.782 & 0.538 \\
PR & 0.797 & 0.837 & 0.593 \\
SI & 0.772 & 0.830 & 0.559 \\
\hline \hline
\end{tabular}


3.4 Path Coefficient Result

Table 5 Path Coefficient Result

$\begin{array}{ccccc}\text { Original } & \text { Sample } & \text { Standard } & \text { T Statistics } & \text { P } \\ \text { Sample } & \begin{array}{c}\text { Mean } \\ \text { (O) }\end{array} & \begin{array}{c}\text { Deviation } \\ \text { (M) }\end{array} & \begin{array}{c}\text { (STDEV) } \\ (\mid \mathrm{O} / \text { STDEV } \mid)\end{array} & \text { Values }\end{array}$

Dependent: INT

\begin{tabular}{lrllll}
\hline \hline LK $\rightarrow$ INT & 0.101 & 0.100 & 0.028 & 3.636 & $0.000^{*}$ \\
LS $\rightarrow$ INT & 0.392 & 0.394 & 0.042 & 9.270 & $0.000^{*}$ \\
RP $\rightarrow$ INT & 0.251 & 0.253 & 0.038 & 6.656 & $0.000^{*}$ \\
SI $\rightarrow$ INT & 0.221 & 0.221 & 0.040 & 5.533 & $0.000^{*}$
\end{tabular}

$\begin{array}{ll}\mathrm{R} \text { square } & 0.602\end{array}$

$\begin{array}{ll}\text { R square Adjusted } & 0.589\end{array}$

\begin{tabular}{lrrrrrr}
\hline Dependent: FD & & & & & & \\
\hline RP $\rightarrow$ FD & -0.060 & -0.056 & 0.052 & 1.143 & 0.254 & \\
LS $\rightarrow$ FD & 0.291 & 0.289 & 0.060 & 4.821 & $0.000^{*}$ & \\
SI $\rightarrow$ FD & -0.066 & -0.064 & 0.054 & 1.211 & 0.227 & \\
LK $\rightarrow$ FD & 0.291 & 0.289 & 0.060 & 4.821 & $0.000^{*}$ & \\
INT $\rightarrow$ FD & 0.299 & 0.298 & 0.058 & 5.124 & $0.000^{*}$ & \\
R square & & & & & & 0.385 \\
R square Adjusted & & & & & & 0.379 \\
\hline \hline
\end{tabular}

* significant at the $1 \%$ level

** significant at the 5\% level

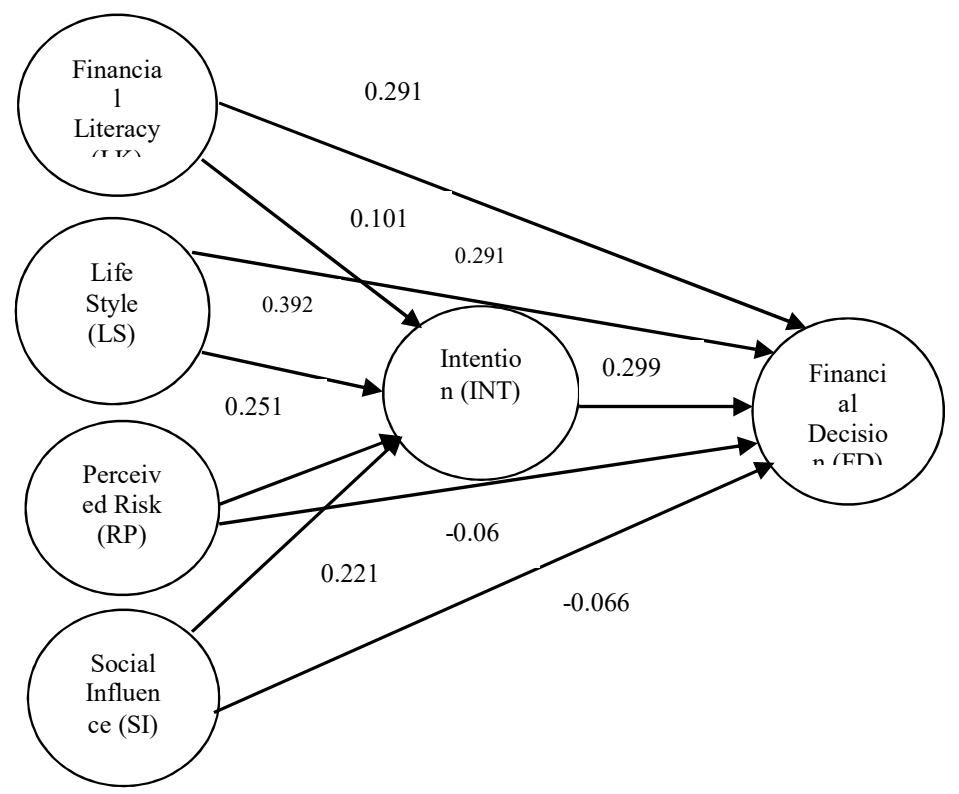

Figure 1 Theoretical Model \& SPLS Result 
Table 5 represents the result of statistical analysis by using smart PLS to determine the aspects that influence millennial Islamic financial products decision. Moreover, figure 1 explaines the theoretical model that is used to describe the relationship among variables. Table 5 also shows that most of hypothesis is statistically significant at $1 \%$ level. Islamic financial literacy is expected to improve millennial understanding related to Islamic financial products. Hypothesis 1 is supported, and path coefficient shows positive relationship which represents the high level of Islamic financial literacy impacts the higher millennial intention in using Islamic financial products. Islamic principles have several guidance for individual, it includes direction in financial products principle. Millennial who has better understanding in Islamic finance usually interest in Islamic financial products, since it applies the sharia base and muslim should avoid riba practice. The finding is consistent with study by Lopus, Amidjono, \& Grimes (2019); Kim \& et.al. (2017); Weedige \& et. al. (2019).

Today, with the rapid of technology development, millennial are able to receive Islamic information from any resources. The information will help them to enhance their Islamic knowledge and implement Islamic principle in daily activities. Financial products, are also part of their consideration which quite different compare to conventional financial products. According to Moosavian (2007), there are several fundamental in Islamic finance, such as: there is no intrinsic value in money and it is consider only for exchange instrument, especially to assess products and services value; implement the risk and return sharing; avoid the destrucive activities in society, such as gambling, drink/ trading alcoholic drinks; do not employ riba and gharar. The finding of this study is supported that Islamic literacy will help millennial to choose islamic financial products. It is consistent with previous study by Lopus, Amidjono, $\&$ Grimes (2019); Kim \& et.al. (2017), Putri $\&$ Lestari (2019). It is suggested that government and financial institution should provide information for Indonesian millennial related to islamic finance in order to improve their islamic finance understanding.

Every generation exhibit different type of lifestyle. Lifestyle, generally captures individual habit. Millennial who consistent to employ islamic lifestyle, usually have higher intention to use islamic financial products since the product is represented their daily behavior. The result will be difference compare to other millennial who do not implement islamic principle in their daily life. The result shows that islamis lifestyle affect 
millennial intention in using islamic financial products. While the positive coefficient reflects the positive relationship in measuring the impact. It can be explained that the more islamic lifestyle, millennial will tend to have higher intention to use islamic financial products. The result is consistent with Qing, Lobo, \& Chongguang (2012); Ahmad, Omar, \& Ramayah (2010).

The continuity and practical execution of behavior will form individual lifestyle. The islamic lifestyle should implement several consideration and do not contrast with sharia principles. Millennial who provide steady islamic lifestyle will decide to use islamic products/ services, including financial products. According to Al-Dmour \& et. al. (2017); Anitha (2016) lifestyle will help individual in decision making process, it drives individual to make decision related to their habitual activities. Hypothesis four is supported at $1 \%$ of significant level. Islamic law, basically attempts to build suitable environment to implement morality, enjoy spiritual life, and improve both socio and economic well being. It is expected that islamic lifestyle will represent in islamic financial products decision. Financial institution should consider to create innovative products and campaign that fit with the latest trend and millennial lifestyle.
Financial products consist of various type with different characteristic in their product. The complex consideration in financial products is the risk that may exist when individual decice to purchase. Risk and return are investment package that basically become the first investors' attention. High risk financial product usually generates higher return compare to low risk financial product. However, investors relatively have different preference related to risk level. Furthermore, investors will perceive any risk level of financial products that they will consider. Hypothesis five is supported and statistical analysis shows positive corelation which can be concluded, the more millennial perceive islamic products are safe (low-risk), they will have more intention to buy the product. The result is consitent with Lestari (2019); Trang \& Tho (2017). The finding suggest that government should provide regulation in order to minimize the consumer financial risk in using financial products.

Hypothesis six is rejected, perceived risk does not influence millennial decision in using islamic financial products. The result shows, there is tendency that millennial perceive another aspect of islamic financial product because islamic products are perceive as halal, riba free, and implement the sharia law which is stated in Quran and Hadist. Risk and 
return are given, and Indonesian muslim do not take too much consideration regarding the product risk. They concern more related to the Sharia principle in islamic products. As long as the product is in Sharia-based, they will consider to use the product. This finding is not consistent with previous study by Sindhu \& Kumar (2014), and Hong \& Yi (2012).

Indonesian are relatively possess good relationship with their family and friends. They love to socialize, and show high bonding level with their family. Social influence which include reference group become an important factor to determine individual behavior, including in financial products. Hypothesis seven is statistically significant at $1 \%$ level which explain, social influence is important aspect to influence millennial intention in using islamic financial products. Islamic culture that is brought, or islamic influencer in both conventional and new media may affect individual consideration in decision making process. For instance, islamic culture in a family who tend to use hijab will rise sense of intention to use hijab among family member. The result is supported by Butcher, Sparks, \& O'Callaghan (2002); Wang \& Chou (2014). The implication of this finding is, financial institution should promote campaign that involves reference group and manage creative content to promote the social issue.

Islamic value has became deeprooted in Indonesia culture, and it has been part of Indonesia culture, such as the use of hijab and several traditions that have been adjusted related to islamic value. In general, Indonesian have implemented the islamic principle in day to day activities. Family and other group reference are one of instrument that are prejected to influence individual decision making. However, this study finds that social influence do not effect millennial decision making in using islamic financial products. The finding basically represents millennial characteristic which is portrayed millennial creativity in complex decision making, independent, and active learning. In islamic financial products decision making, millennial tend to become indepent and do not follow others opinion. The finding is not consistent with study by FLórez \&e et. al. (2018).

The last hypothesis is statistically significant at $1 \%$ level which describes the higher level of millennial intention will lead them to use islamic finance products. Intention usually drives individual behavior which can be defined as individual motive, plan, and purpose. It usually reflects on individual activities, especially in decision making, because individual should evaluate the reason and 
impact of their decision. Financial institution should aware the millennial decision making process and formulate the suitable campaign for muslim to enhance their intention level in order to help them to create financial decision.

\section{Concluding Remarks}

This paper attempts to determine the millennial behavior in using Islamic financial products. The rise of the digital news provides opportunity for individual in gaining information, including related to have better understanding in sharia principle. Today, Indonesians are aware on Islamic regulation which involves most of their day to day activities. The result of this study shows that Islamic financial literacy, Islamic lifestyle, perceived risk, and social influence affect the millennial intention to use Islamic financial products. However, only two variables affect millennial decision making in using Islamic financial products: Islamic financial literacy and Islamic lifestyle. Intention can be interpreted as individual motives which are expected to be executed. Millennial understanding in Islamic principles, millennial habbit which represented by their Islamic lifestyle in daily activities, how they perceive risk compare to return in Islamic financial product, and social aspects that may change millennial view in using a product/ service are determinant which influence millennial intention in using financial products. Moreover, the result shows that social influence and perceived risk do not affect millennial actual behavior in using Islamic financial products. The finding basically describe the Indonesian muslim millennial characteristic who are relatively independent in decision making process since they do not consider social aspect and do not consider any risk aspect related to Islamic financial products. Other variables which are found to have strong effect on millennial decision making are Islamic financial literacy and Islamic lifestyle which explain how better understanding in Islamic principle and Islamic habbit influence millennial decision in using Islamic financial products.

\section{Suggestion}

The result of this study basically provides several implications for academics, firm management, and government. Firm management should aware the latest trend of financial products, innovative with technologicalbased, and implement the sharia law since Indonesian millennial quite aware with sharia implementation and intent to have better understanding regarding to Islamic financial literary and employ the Islamic lifestyle in their daily activities. However, this paper contains several limitations and 
recommendation is provided for future research in order to tackle the research limitation. Firstly, the data collection should be more various and distributed to several Indonesia big cities with have fast muslim population to gain more data and will be more sufficient to generalize the result. Secondly, this study has not considered the psychological aspect of Indonesian muslim in financial product consideration. It is better for the future research to examine the psychogical factors in order to explore individual insight regarding to decision making process and individual behavior, such as self esteem, locus of control, and other variables that may suitable with the goal of study. Thirdly, the future research should investigate the sharia aspects, such as profit-loss sharing practice in Islamic financial institution. Lastly, the next research may employ other statistical tool such AMOS, lisrel, etc.

\section{Refferences}

Ahmad, N., Omar, A., \& Ramayah, T. (2010). Consumer Lifestyles and Online Shopping Continuance Intention. Business Strategy Series, Vol. 11 No. 4, 227-243.

Al-Dmour, R., \& et. al. (2017). The Effect of Lifestyle on Online Purchasing Decision for Electronic Services: The Jordanian Flying E-Tickets Case. Asian Social Science, Vol. 13, No. $11,157-169$.

Alharbi, A. (2015). Development of the Islamic Banking System. Journal of
Islamic Banking and Finance, Vol.3, No. 1, $12-25$.

Anitha, N. (2016). Influence of Lifestyle on Consumer Decision Making with Special Reference to Organized Retail Formats in Chennai. Indian Journal of Commerce \& Management Studies, Vol. VII Issue 1, 85-91.

Ashor, E. S. (2018). Mengapa Produk Perbankan Syariah Banyak Diminati Non-Muslim? . Retrieved January 3, 2020, from https://sharianews.com: https://sharianews.com/posts/men gapa-produk-perbankan-syariahbanyak-diminati-non-muslim

Butcher, K. J., Sparks, B., \& O'Callaghan, F. (2002). Effect of social influence on repurchase intentions. Journal of Services Marketing Vol. 16 Iss 6 , 503514.

FLórez, L. E., \& et. al. (2018). Influence of Social Networks on The Purchase Decisions of University Students. Cuadernos de Gestión, Vol. 18, No. 1, 6184.

Gedmintiene, D. D., \& Visockaite, A. (2016). The Importance of Personal Finance for Investment and Applying Financial Behaviour Principle in Personal Finance Investment Decisions in Lithuania. Socialiniu Mokslu Studijos Societal Studies 8 (1), 118-131.

Hong, Z., \& Y Yi, L. (2012). Research on the Influence of Perceived Risk in Consumer Online Purchasing Decision. Physics Procedia 24 , 13041310.

Imady, O., \& Seibel, H. D. (2006). Principles and Products of Islamic Finance. Working Paper, No. 2006,1.

jakpat. (2918). Indonesian Millennials Investment Trend 2018 -Survey Report. Retrieved December 18, 2019, from blog.jakpat.ne: https://blog.jakpat.net/indonesianmillennials-investment-trend2018-survey-report/ 
Janor, H., \& et. al. (2016). Financial Literacy and Investment Decisions in Malaysia and United Kingdom: A Comparative Analysis. Malaysian Journal of Society and Space 12 issue 2, $106-118$.

Kettani, H. (2010). World Muslim Population: 1950-2020. International Journal of Environmental Science and Development (IJESD), Vol. 1, No. 2.

Kim, J., \& et.al. (2017). Review of Family Financial Decision Making:Suggestions for Future Research and Implications for Financial Education. Journal of Financial Counseling and Planning, Vol. 28, No. 2, 253-267.

Lestari, D. (2019). Measuring E-commerce Adoption Behaviour Among Gen-Z in Jakarta, Indonesia. Economic Analysis and Policy, Vol. 64, 103-115.

Lopus, J. S., Amidjono, D. S., \& Grimes, P. W. (2019). Improving Financial Literacy of the Poor and Vulnerable in Indonesia: An Empirical Analysis. International Review of Economics Education 32.

Lusardi, A. (2008). Financial Literacy: an Essential Tool for Informed Consumer Choice? . NBER Working Paper Series.

Mohiuddin, Z. A. (2018). Effect of Lifestyle on Consumer Decision Making: A Study of Women Consumer of Pakistan. Journal of Accounting, Business and Finance Research, Vol. 2, No. 1, 12-15.

Moosavian, S. A. (2007). Islamic Banking (in Farsi). Tehran: Monetary and Banking Research Institute.

Otoritas Jasa Keuangan. (2018). Snapshot of Indonesia Islamic Banking Development. Otoritas Jasa Keuangan.

Putri, N. A., \& Lestari, D. (2019). Pengaruh Gaya Hidup dan Literasi Keuangan Terhadap Pengelolaan Keuangan Tenaga Kerja Muda di Jakarta. Akurasi: Jurnal Riset Akuntansi dan Keuangan, Vol 1, No.1, 31-42.
Qing, P., Lobo, A., \& Chongguang, L. (2012). The impact of Lifestyle and Ethnocentrism on Consumers' Purchase Intentions of Fresh Fruit in China. Journal of Consumer Marketing, 29 (1), 43-5l.

Sindhu , \& Kumar, R. (2014). Influence of Risk Perception of Investors on Investment Decisions: An Emperical Analysis. Journal of Finance and Bank Management Vol.2, No. 2, 15-25.

Suhartono, H. (2018). Millennials Rule Over Indonesian Stock Market as Foreigners Flee. Retrieved December 18, 2019, from www.thejakartapost.com: https://www.thejakartapost.com/n ews/2018/11/23/millennials-ruleover-indonesian-stock-market-asforeigners-flee.html

Trang, P. T., \& Tho, N. H. (2017). Perceived Risk, Investment Performance and Intentions in Emerging Stock Markets. International Journal of Economics and Financial Issues, 7 (1), 269-278.

Wang, E. S.-T., \& Chou, N. P.-Y. (2014). Consumer Characteristics, Social Influence, and System Factors on Online Group-Buying Repurchasing Intention. Journal of Electronic Commerce Research, Vol. 15, No.2.

Weedige, S. S., \& et. al. (2019). Decision Making in Personal Insurance: Impact of Insurance Literacy. Sustainability, 11, 6795.

Williams, C. (2007). Research Methods. Journal of Business \& Economic Research, Vol. 5, No. 3, 65-72. 